\title{
Efficiency Analysis of Bank Branches: Production and Profitability Approaches (Case Study of Bank EFG Syariah)
}

\author{
Deny Syaiful Hayat ${ }^{1}$, Lukytawati Anggraeni ${ }^{2}$, Toni Bakhtiar ${ }^{3}$ \\ ${ }^{1}$ School of Business, Bogor Agricultural University (IPB), Jl. Raya Pajajaran Bogor, Indonesia 16151, West Java, Indonesia \\ ${ }^{2}$ Department of Economics, Faculty of Economics and Management, Bogor Agricultural University (IPB), \\ Jl. Raya Darmaga Kampus IPB Darmaga Bogor 16680 West Java, Indonesia \\ ${ }^{3}$ Department of Mathematics, Faculty of Mathematics and Physics, Bogor Agricultural University (IPB), \\ Jl. Raya Darmaga Kampus IPB Darmaga Bogor 16680 West Java, Indonesia
}

\begin{abstract}
Until 2015, market share of Indonesian Islamic banking was still below of total 5\% Indonesian banking market share. One effort to increase the market share is to spin off its Islamic business unit into Islamic commercial banks. One of the banks that undergoes the process was Bank EFG Syariah. However,Bank EFG Syariah has not been showing an optimal performance, which is indicated by reduced levels of corporate profitability in 2015. The aim of this study was to develop a performance model for measuring the relative efficiency and potential improvement capabilities of Bank EFG Syariah branches for the period 2014 and 2015. Data Envelopment Analysis (DEA) technique is utilitized here under production and profitability models. Another purpose was to investigate the production and profitability aspects of branches and to measured productivity change of Bank EFG Syariah branches between period. In this study the nature of efficiency and productivity change was investigate through the Malmquist Index. The results showed that there was an increase of $6 \%$ in high production-high profitable branches group, a decreased of $8 \%$ of the low production-high profitable branches group, a decreased of $7 \%$ the high production-low profitable branches group, and an increased of $4 \%$ in low production-low profitable branches group. This reasearch also showed the average productivity increase of branches Bank EFG Syariah, between the period 2014-2015.
\end{abstract}

Keywords: Bank branches, DEA, Efficiency, Productivity, Malmquist Index

\section{Introduction}

In recent years, the growth of Islamic banking in Indonesia is slower than that of the overall Indonesian banking sector. The growth of the market share of Indonesian Islamic banking can not reach more than $5 \%$ of the overall market share (Figure 1).

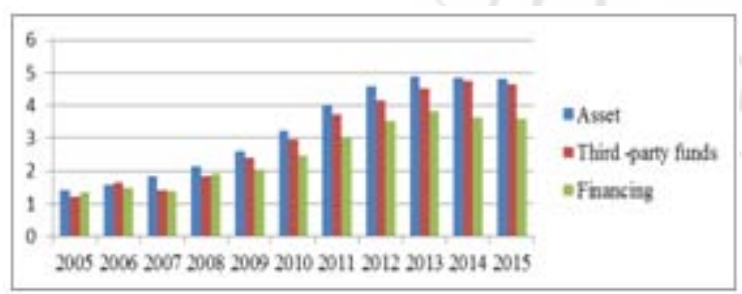

Figure 1: The development of Islamic banking market share of the national banking system in the period 2005-2015 (\%) Source: Otoritas Jasa Keuangan, 2016

Based on these conditions, Otoritas Jasa Keuangan (OJK) as the government agency that regulates and supervises the nation's financial services sector, encourages conventional commercial banks in Indonesia to spin off their Islamic business units. Bank EFG Syariah is one of the banks that experienced the spin-off process. Unfortunately, the performance of Bank EFG Syariah has not achieved satisfactory results, particulary in 2015. Table 1 shows the financial performance of the Bank EFG Syariah during the period 2013-2015 indicates inefficiencies in Bank EFG
Syariah operations.

Table 1: The financial performance of Bank EFG Syariah in the period 2013-2015

\begin{tabular}{|c|c|c|c|}
\hline & $\mathbf{2 0 1 3}$ & $\mathbf{2 0 1 4}$ & $\mathbf{2 0 1 5}$ \\
\hline Asset (Rp. Billion) & 4707 & 6099 & 6445 \\
\hline Financing (Rp. Billion) & 3553 & 4333 & 4928 \\
\hline Third-party funds (Rp. Billion) & 3122 & 4622 & 4702 \\
\hline Profit (Rp. Billion) & 42.59 & 43.75 & 6.85 \\
\hline NPF (\%) & 1.86 & 3.91 & 6.84 \\
\hline FDR (\%) & 113.79 & 84.02 & 95.50 \\
\hline ROA (\%) & 6.68 & 0.88 & 0.11 \\
\hline ROE (\%) & 1.00 & 5.39 & 0.66 \\
\hline
\end{tabular}

Study on the measurement of the efficiency of banks has been widely applied in various countries in the world, including in Indonesia. Repkova (2014) conducted a study of banking efficiency in the Czech Republic, then Titko (2014) conducted a study of banking efficiency in new countries joined the European Union, while Eken and Kale (2013) conducted a similar study in Turkey. Meanwhile, in Indonesia, banking efficiency studies has been conducted by Hosen and Shafritanata (2014), Havidz and Setiawan (2015), and Hidayati et al. (2015).

The study on the efficiency of bank branches has also been widely studied in the world. Kaveh (2009) conducted a study on the efficiency of bank branches of Bank of Iran, followed by Nashtaei and Paskiabi (2013) conducted a study on Bank Melli, Iran. Then, Paradi et al. (2015) conducted a study of

\section{Volume 6 Issue 2, February 2017




\section{International Journal of Science and Research (IJSR) \\ ISSN (Online): 2319-7064}

Index Copernicus Value (2015): 78.96 Impact Factor (2015): 6.391

the bank branches efficiency in one of the biggest banks in Canada. Eken and Kale (2011) conducted a study on the efficiency of bank branches Istanbul, Turkey. Meanwhile, in Indonesia, the study of the efficiency of bank branches is still rare, due to lack of data.

Based on the research gap, this current study deviates from previous study in one respects. This study examines the efficiency of branches in one bank in Indonesia with two models, namely production and profit model. Thus, the purpose of this study is as follows:

1)Measure and analyze the efficiency of bank branches of Bank EFG Syariah in the period 2014-2015, by using Data Envelopment Analysis (DEA) under production and profitability approaches.

2)Measure and analyze changes in productivity of the branches of Bank EFG Syariah in the period 2014 and 2015 by using Malmquist Index.

\section{Data}

This study uses secondary data from the financial statements of the 62 branches of the Bank EFG Syariah over the period 2014-2015. Two models were proposed in the analysis of efficiency and productivity changes, namely the production and profitability models. Table 2 contains the information of inputs and outputs used in this study.

Tabel 2: Models and their Inputs and Outputs

\begin{tabular}{|c|c|c|c|}
\hline Model & Inputs & Outputs & Source \\
\hline Production & $\begin{array}{l}\text { Third party share } \\
\text { on return expenses } \\
\text { - Personal expenses } \\
\text { - Non Operating } \\
\text { expenses } \\
\text { - Provision for } \\
\text { possible losses on } \\
\text { earning assets }\end{array}$ & $\begin{array}{l}\text { - } \text { Total } \\
\text { production } \\
\text { financing } \\
\text { - Total } \\
\text { consumer } \\
\text { financing } \\
\text { - Total third } \\
\text { party funds }\end{array}$ & $\begin{array}{c}\text { Balance } \\
\text { sheet and } \\
\text { profit and } \\
\text { loss }\end{array}$ \\
\hline Profit & $\begin{array}{l}\text { - Third party share } \\
\text { on return expenses } \\
\text { - Personal expenses } \\
\text { - Non Operating } \\
\text { expenses } \\
\text { - Provision for } \\
\text { possible losses on } \\
\text { earning assets }\end{array}$ & $\begin{array}{l}\text { - Fund } \\
\text { management } \\
\text { income } \\
\text { - Others } \\
\text { operating } \\
\text { income }\end{array}$ & $\begin{array}{c}\text { Profit and } \\
\text { loss }\end{array}$ \\
\hline
\end{tabular}

Production models used to measure the ability of the bank branches in generating banking products using its input resources. And profitability models used to measure the ability of the bank branches in generating revenue by using inputs. The inputs used in this study relates to the achievement of financing provided to the customer, because the higher of these inputs expenses, the higher interest expense will be charged to the customers and the more difficult to sell such financing. While the achievement of third party funds are related to non-operating expenses which is a proxy of the costs incurred when a branch lack of third-party funds. The higher non-operating expenses reflects the low achievement of third party funds. others operating incomes. The higher of input expenses, the lower of achievement of both these incomes.

\section{Metodhology}

\subsection{Data Envelopment Analysis (DEA)}

The measurement of efficiency of bank branches using two models, the production and profit model. The production model is used to measure the ability of bank branches uses its resources to generate third party funds and financing. Meanwhile, the profit model is used to measure the ability of bank branches in using its resources to generate profits, which are proxied by fund management income and others operating income.

\subsection{Malmquist Index}

Malmquist index is used to measure the productivity change of bank branches that occurred during the period 2014 and 2015. Furthermore, the results from the measurement Malmquist Index, followed by analyzing the source of the productivity changes, which consists of efficiency change (catch-up effect), technological change (frontier shift effect) and changes in both effects.

\section{Empirical Results and Analysis}

\subsection{Efficiency score}

Based on the production model, the results of measurement of the efficiency of bank branches in 2014 and 2015 is shown in Table 3. In 2015, the number of technically efficient branches increased by one, when compared with conditions in 2014. While the number of branches are included in the category of purely technical efficient unchanged to the previous year.

Table 3: Efficiency measurement results in the production

\begin{tabular}{|c|c|c|c|c|}
\hline & \multicolumn{2}{|c|}{2014} & \multicolumn{2}{c|}{2015} \\
\hline & $\begin{array}{c}\text { Technica } \\
1\end{array}$ & $\begin{array}{c}\text { Purely } \\
\text { technica } \\
1\end{array}$ & Technical & $\begin{array}{c}\text { Purely } \\
\text { technical }\end{array}$ \\
\hline Efficient branches & 40 & 47 & 41 & 47 \\
\hline Non efficient branches & 22 & 15 & 21 & 15 \\
\hline Average & 0.93 & 0.95 & 0.94 & 0.97 \\
\hline Std. Deviation & 0.12 & 0.11 & 0.12 & 0.08 \\
\hline Maximum & 1 & 1 & 1 & 1 \\
\hline Minimum & 0.50 & 0.52 & 0.46 & 0.56 \\
\hline
\end{tabular}

The results of measurement of the efficiency with profit model is shown in Table 4. The measurement results indicate there is an increasing number of technically efficient branches and pure technically efficient branches from the period 2014 to 2015 . Total technically efficient branches increased by 3 branches, while the number of pure technically efficient branches increased by 8 .

Inputs used are also related to the fund management and 


\section{International Journal of Science and Research (IJSR) \\ ISSN (Online): 2319-7064}

Index Copernicus Value (2015): 78.96 | Impact Factor (2015): 6.391

Table 4: Efficiency measurement results in the profit model

\begin{tabular}{|l|c|c|c|c|}
\hline & \multicolumn{2}{|c|}{2014} & \multicolumn{2}{c|}{2015} \\
\hline & $\begin{array}{c}\text { Technica } \\
1\end{array}$ & $\begin{array}{c}\text { Purely } \\
\text { technical }\end{array}$ & Technical & $\begin{array}{c}\text { Purely } \\
\text { technical }\end{array}$ \\
\hline Efficient branches & 24 & 29 & 27 & 37 \\
\hline Non efficient branches & 38 & 28 & 35 & 25 \\
\hline Average & 0.85 & 0.90 & 0.92 & 0.94 \\
\hline Standar Deviation & 0.17 & 0.15 & 0.12 & 0.09 \\
\hline Maximum & 1 & 1 & 1 & 1 \\
\hline Minimum & 0.15 & 0.18 & 0.51 & 0.68 \\
\hline
\end{tabular}

From the measurement of technical efficiency with production and profitability models, then the branches are grouped into four groups, as follows:

- Group 1, high production-high profit branches

- Group 2, low production-high profit branches

- Group 3, high production-low profit branches

- Group 4, low production-low profit branches

Figure 2 shows that the number of branches grouped by level of efficiency with the production and profitability models in 2014. Based on Figure 2, 34\% of the branches are categorized as high production-low profit, $31 \%$ of the branches are categorized as high production-high profit, 27\% of the branches are categorized as low production-low profit, and the remaining branches belonging to the category as low production-high profit.

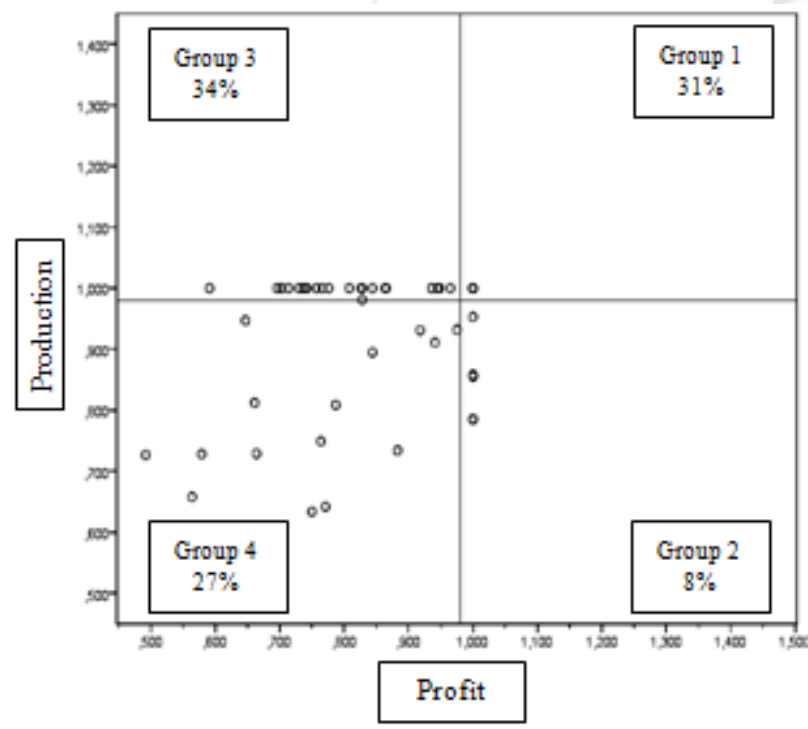

Figure 2: Groups of branches based on production and profit models in 2014

Branches grouping for 2015 is depicted in Figure 3. From the figure it can be concluded there are improvements in efficiency compared to 2014, which indicated an increase of $37 \%$ of the number of branches in high production-high profit group. The remaining of 5\% branches including low production-high profit group, $27 \%$ were calssified as branches of high production-low profit group, and $31 \%$ of branches joined in low production- low profit group.

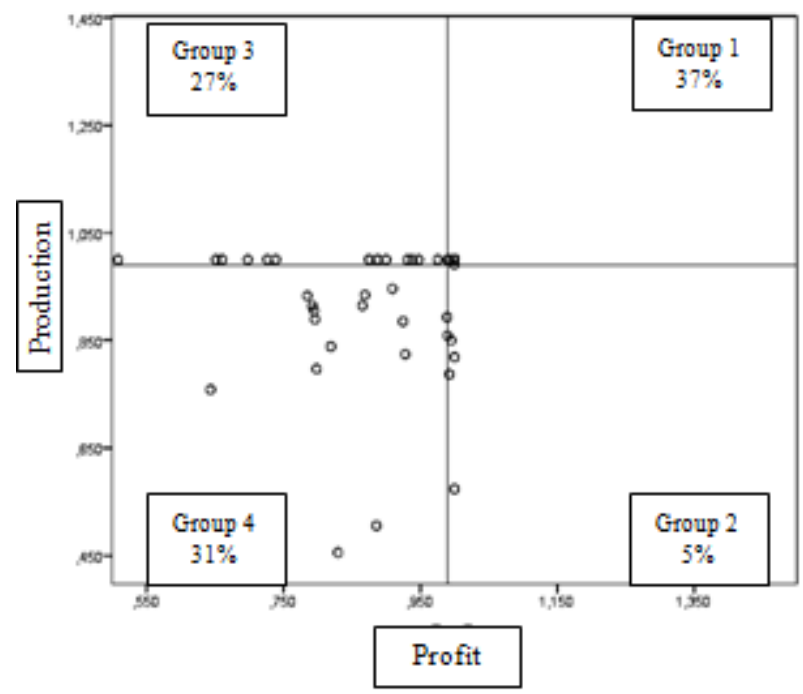

Figure 3: Groups of branches based on production and profit models in 2015

Potential of efficiency improvement in 2015 with production model of consolidated bank as shown in Table 5. The highest potential improvement noted by non operating expenses, amounting 13,60\%. Non-operating Expenses consist of benefit expense (revenue-sharing) between branches issued when an event requires funding from other branches, for the purposes of the distribution of funding to the debtor. This condition occurs when a branch of lacks of liquidity or its Financing to Deposit Ratio (FDR) level exceeds 100\%.

Table 6: Potential improvements in 2015 with the production model

\begin{tabular}{|c|c|c|c|c|}
\hline Inputs and Outputs & $\begin{array}{c}\text { Actual } \\
\text { (Rp. } \\
\text { Milion) }\end{array}$ & $\begin{array}{c}\text { Potential } \\
\text { (Rp. Milion) }\end{array}$ & $\begin{array}{c}\text { Difference } \\
\text { (Rp. Milion) }\end{array}$ & $\%$ \\
\hline $\begin{array}{c}\text { Third party share } \\
\text { on return expenses }\end{array}$ & 378,32 & 379,03 & $(703)$ & $-0.2 \%$ \\
\hline Personal expenses & 78,37 & 78,93 & $(560)$ & $-0.7 \%$ \\
\hline $\begin{array}{c}\text { Non Operating } \\
\text { expenses }\end{array}$ & 290,36 & 329,78 & $(39,422)$ & $-13.6 \%$ \\
\hline $\begin{array}{c}\text { Provision for } \\
\text { possible losses on } \\
\text { earning assets }\end{array}$ & 203,97 & 219,73 & $(15,761)$ & $-7.7 \%$ \\
\hline $\begin{array}{c}\text { Total production } \\
\text { financing }\end{array}$ & $2,191,64$ & $2,381,67$ & 190,033 & $8.7 \%$ \\
\hline $\begin{array}{c}\text { Total consumer } \\
\text { financing }\end{array}$ & $2,707,82$ & $3,025,71$ & 317,888 & $11.7 \%$ \\
\hline $\begin{array}{c}\text { Total third party } \\
\text { funds }\end{array}$ & $4,687,05$ & $5,156,47$ & 469,426 & $10.0 \%$ \\
\hline
\end{tabular}

Potential improvements in 2015 through the profit model showed different results with the production model (see Table 7). Potential improvement of the provision for possible losses on earning assets has the largest share of potential improvements to be made, amounting to $44.50 \%$. Provision for possible losses on earning assets is a reflection of the high level of NPF of Bank EFG Syariah consolidated. 


\section{International Journal of Science and Research (IJSR) \\ ISSN (Online): 2319-7064}

Index Copernicus Value (2015): 78.96 Impact Factor (2015): 6.391

Table 7: Potential improvements in 2015 with the profit model

\begin{tabular}{|c|c|c|c|c|}
\hline Inputs and Outputs & $\begin{array}{c}\text { Actual } \\
\text { (Rp. } \\
\text { Milion) }\end{array}$ & $\begin{array}{c}\text { Potential } \\
\text { (Rp. } \\
\text { Milion) }\end{array}$ & $\begin{array}{c}\text { Differenc } \\
\text { e (Rp. } \\
\text { Milion) }\end{array}$ & $\%$ \\
\hline $\begin{array}{c}\text { Third party share on } \\
\text { return expenses }\end{array}$ & 378,32 & 380,45 & $(2,12)$ & -0.6 \\
\hline Personal expenses & 78,37 & 1,71 & $(3,34)$ & -4.3 \\
\hline $\begin{array}{c}\text { Non Operating } \\
\text { expenses }\end{array}$ & 290,36 & 290,85 & $(492)$ & -0.2 \\
\hline $\begin{array}{c}\text { Provision for possible } \\
\text { losses on earning } \\
\text { assets }\end{array}$ & 203,97 & 294,78 & $(90,80)$ & -44.5 \\
\hline $\begin{array}{c}\text { Fund management } \\
\text { income }\end{array}$ & 696,74 & 750,47 & 53,72 & 7.7 \\
\hline $\begin{array}{c}\text { Others operating } \\
\text { income }\end{array}$ & 334,35 & 344,01 & 9,65 & 2.9 \\
\hline
\end{tabular}

\subsection{Malmquist Index results}

The results of measurements Malmquist index of Bank EFG Syariah branches during the period 2014-2015 with production model shown by Table 8 . The results presented that the average value of Malmquist index of Bank EFG Syariah branches is 1,05 . Average productivity growth is caused by the catch-up effect on average by 1,02 and frontier shift effect by 1,03 . Of the total 62 branches, there are branches that decreased productivity as much as 40 branches, while the branches that increased productivity are as much as 22 branches.

Table 8: Malmquist index measurement results with the production model

\begin{tabular}{|c|c|c|c|}
\hline & $\begin{array}{c}\text { Technical } \\
\text { efficiency } \\
\text { change }\end{array}$ & $\begin{array}{c}\text { Technology } \\
\text { change }\end{array}$ & $\begin{array}{c}\text { Malmquist } \\
\text { Index }\end{array}$ \\
\hline Average & 1.02 & 1.03 & 1.05 \\
\hline Maximum & 1.72 & 4.67 & 4.67 \\
\hline Minimum & 0.69 & 0.33 & 0.33 \\
\hline $\begin{array}{c}\text { Standard } \\
\text { Dev. }\end{array}$ & 0.17 & 0.68 & 0.68 \\
\hline
\end{tabular}

Table 9 shows the Malmquist Index of Bank EFG Syariah branches with profit model. Based on the details of each branch, there are 40 branches that have increased productivity, while the rest, as many as 22 branches decreased productivity. On consolidated, the average Malmquist Index amounted to 1,351, which means that the average branches in Bank EFG Syariah increased their productivity based on profit model. Other result is that the average frontier shift effect is greater than the average catchup effect, ie respectively 1.17 and 1.13 . This indicates that productivity changes that occurred in the branches of Bank EFG Syariah are more influenced by catch-up effect rather than frontier shift effect.

Table 9: Malmquist index measurement results with the profit model

\begin{tabular}{|l|c|c|c|}
\hline & $\begin{array}{c}\text { Technical efficiency } \\
\text { change }\end{array}$ & $\begin{array}{c}\text { Technology } \\
\text { change }\end{array}$ & $\begin{array}{c}\text { Malmquist } \\
\text { Index }\end{array}$ \\
\hline Average & 1.13 & 1.17 & 1.35 \\
\hline Maximum & 3.44 & 3.15 & 4.32 \\
\hline Minimum & 0.73 & 0.54 & 0.52 \\
\hline
\end{tabular}

\section{Standard Dev.}

\section{Conclusion}

Based on the results of the studies presented, it can be concluded as follows:

1) There were differences in the number of efficient bank branches of two models. Number of efficient branches of the production model are more than that of profit model.

2) The decrease of provision for possible losses on earning assets and non-operational expenses is the greatest potential improvement in 2015 for improving the efficiency of Bank EFG Syariah.

3) There was productivity growth in Bank EFG Syariah branches between the period 2014-2015, both with production model and the profit model.

4) Technological change had influence on the growth of the productivity of existing branches in Bank EFG Syariah.

\section{References}

[1] I. Řepková I. "Efficiency of the Czech Banking Sector Employing the DEA Window Analysis Approach". Procedia Economics and Finance. 12 (2014). Pp. $587-$ 596. 2014

[2] J.C. Paradi, E. Min, X. Yang. "Evaluating Canadian Bank Branch Operational Efficiency From Staff Allocation: A DEA Approach". Management and Organizational Studies. 2(1). Pp. 52-65. 2015

[3] J. Titko. "DEA Application in Banking: Relationship Between Efficiency Scores and Bank Size". Confrence paper 8th International Scientific Conference "Business and Management 2014". Vilnius Gediminas Technical University. Pp. 345-352. 2014

[4] M.H. Eken, S. Kale. "Measuring bank branch performance using Data Envelopment Analysis (DEA): the case of Turkish bank". African Journal of Business Management. 5(3). Pp. 889-901. 2011

[5] M.H Eken, S. Kale. "Evaluating the Efficiency of Turkish Banks: a Risk and Profitability Approach". The Business and Economics Research Journal. 6(1). Pp. 53-68. 2013

[6] M. Kaveh. "Iranian Bank Branches Performance by Two Stage DEA Model". International Conference on Economics and Finance Research IPEDR Vol. 4. Singapore (SG) : IACSIT Press. 2011

[7] M.N. Hosen, Shafritanata. "Efficiency of Islamic Banks Using Data Envelopment Analysis (DEA) in Indonesia, 2007-2010". International Journal of Academic Research in Economics and Management Sciences. Vol. 3(1). Pp. 223-235.

[8] N. Hidayati, H. Siregar. S.H. Pasaribu. "Islamic Banking: Banking Efficiency Analysis in Indonesia". International Journal of Science and Research. Vol. 5(12). Pp. 1907-1910.

[9] Otoritas Jasa Keuangan Indonesia. Statistik Perbankan Syariah tahun 2005-2015 (Online). Available: http://www.ojk.go.id/id/kanal/syariah/data-danstatistik/statistik-perbankan-syariah/default.aspx [Accessed:Apr.5,2016]

[10] R.A. Nashtaei, M.T. Paskiabi MT. "Determining Efficiency and Rankings Bank Branches of Melli Iran

\section{Volume 6 Issue 2, February 2017}




\section{International Journal of Science and Research (IJSR) \\ ISSN (Online): 2319-7064}

Index Copernicus Value (2015): 78.96 | Impact Factor (2015): 6.391

Using Method of Data Envelopment Analysis (DEA) (Case Study West Area of Rasht-2012)". Singaporean Journal of Business Economics, and Management Studies. 2(4). Pp. 32-37. 2013

[11] S.A.H. Havidz, C. Setiawan. "Bank Efficiency and Non-Performing Financing (NPF) in The Indonesian Islamic Banks". Asian Journal of Economic Modelling. Vol. 3(3). Pp. 61-79

\section{Author Profile}

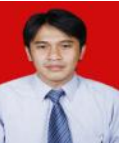

Deny Syaiful Hayat received the B.S. degrees in Agricultural and Resources Economics, Bogor Agricultural University in 2002. During 2003-2010, he worked at PT. Bank Negara Indonesia (Persero) and then continued his career in one of the sharia bank in Indonesia from 2010 until now. He is currently continuing his master studies in School of Business, Bogor Agricultural University 